Investigation of Pollution Extent of Attanagalu Oya: Causes and Effects

Chaamila Dinusha Kumari Pathirana

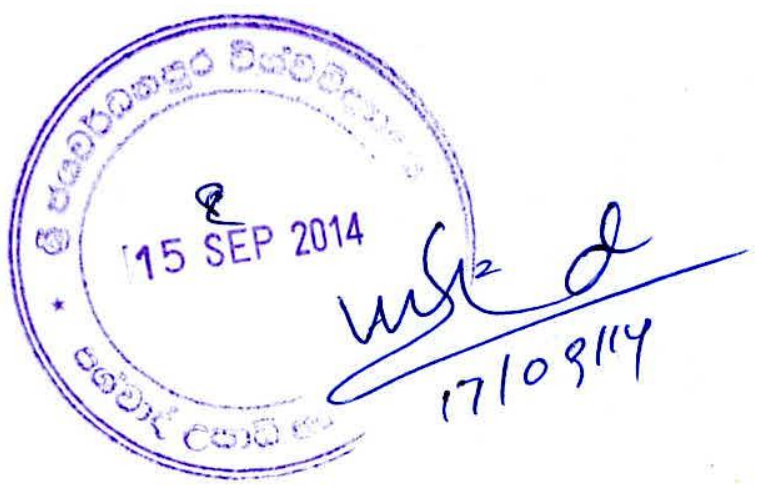

Thesis submitted to the University of Sri Jayewardenepura for the award of Degree of Master of Philosophy in Forestry and Environmental Science on 30th October 2013 


\section{DECLARATION}

The work described in this thesis was carried out by me under the supervision of Prof.

Nilanthi Bandara, Department of Forestry and Environmental Science, Dr. Champa

Jayaweera, Senior Lecturer Department of Chemistry, Faculty of Applied Science, University of Sri Jayewardenepura, Sri Lanka and a report on this has not been submitted in whole or in part to any university or any other institution for another Degree/Diploma.

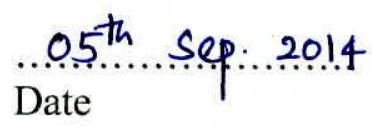

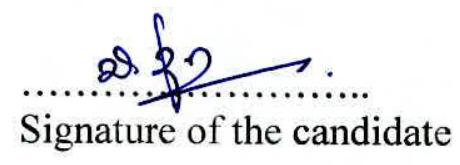




\section{SUPERVISORS' DECLARATION}

We certify that the above statement made by the candidate is true and that this thesis is suitable for submission to the University for the purpose of evaluation.

(2.09.14

Date

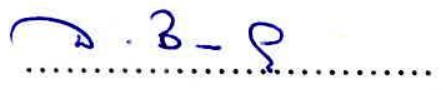

Signature

\section{Supervision}

Prof. Nilanthi Bandara

Department of Forestry and Environmental Science

Faculty of Applied Sciences, University of Sri Jayewardenepura, Nugegoda, Sri Lanka

$$
\frac{12.09 \cdot 2014}{\text { Date }}
$$

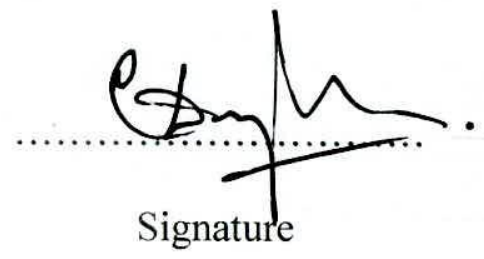

\section{Supervision}

Dr. Champa Jayaweera

Senior Lecturer, Department Chemistry

Faculty of Applied Sciences, University of Sri Jayewardenepura, Nugegoda, Sri Lanka

$$
0.8 \div 09.2014 .
$$

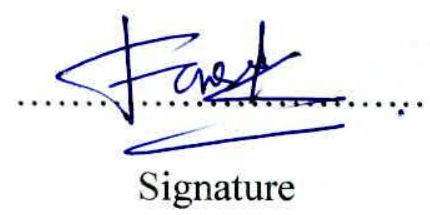

\section{Supervision}

Mr. W. S. C. A. Fonseka

Former Chief Chemist, National Water Supply and Drainage Board

Rathmalana, Sri Lanka 


\section{CERTIFICATION OF THE SUPERVISOR}

Corrections/revisions suggested by the examiners have been carried out/incorporated.

$\sim B-P$

Signature

Prof. Nilanthi Bandara

Department of Forestry and Environmental Science

Faculty of Applied Sciences, University of Sri Jayewardenepura, Nugegoda, Sri Lanka 
Affectionately dedicated

To

My loving Parents, Sister and Yasas

For their endless support, encouragement and endurance 


\section{LIST OF TABLES}

Table 2.1 Rainfall gauging stations of Attanagalu Oya basin........................................ 10

Table 2.2 Important industries within the basin and their locations .............................. 11

Table 2.4 Impact of land use change on water parameters ......................................... 21

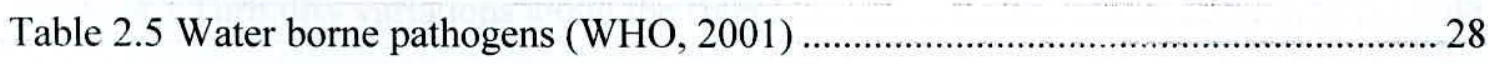

Table 2.6 Microbial removal using water treatments (WHO, 2001) ................................ 29

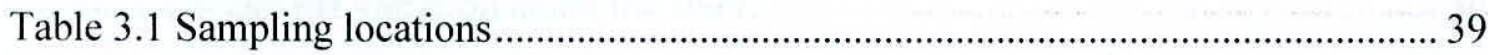

Table 3.2 Parameters and Test methods (APHA, 1998) ................................................ 42

Table 4.1 Water Quality Index during dry and rainy period............................................ 77 


\section{LIST OF FIGURES}

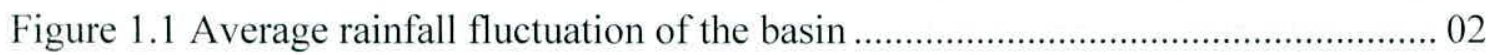

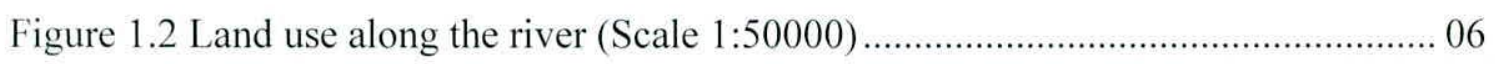

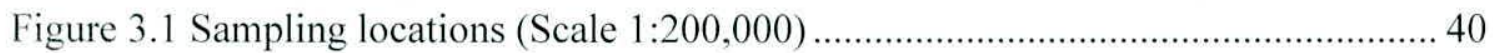

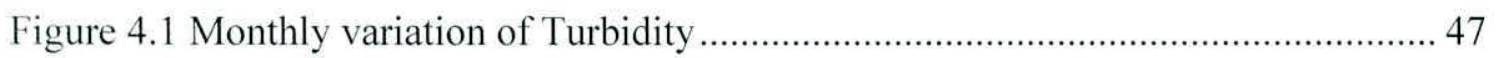

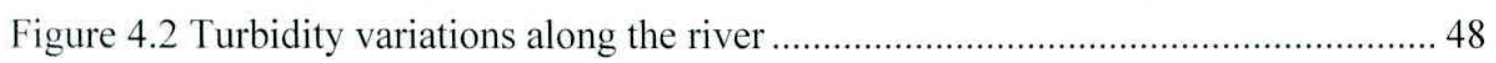

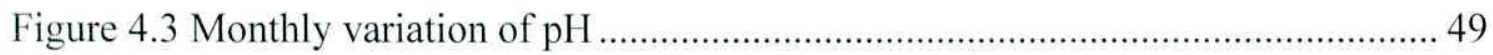

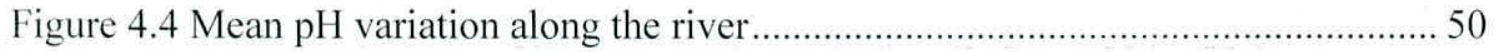

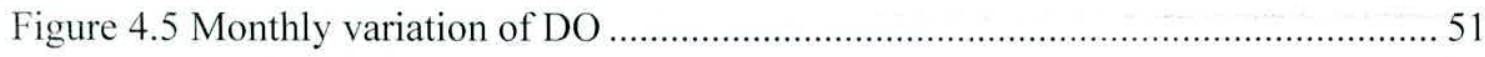

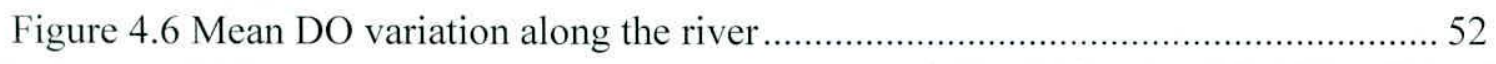

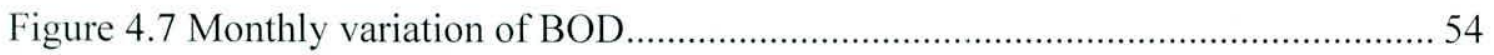

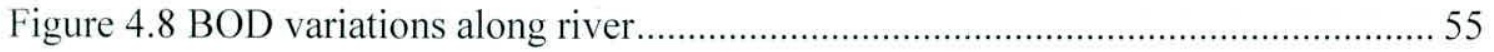

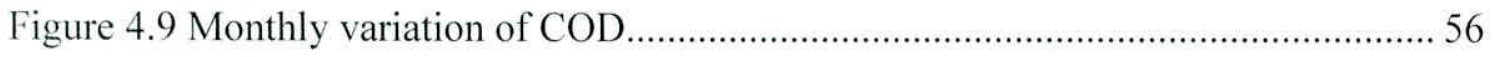

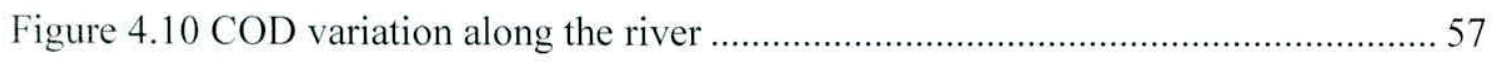

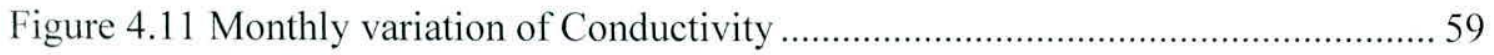

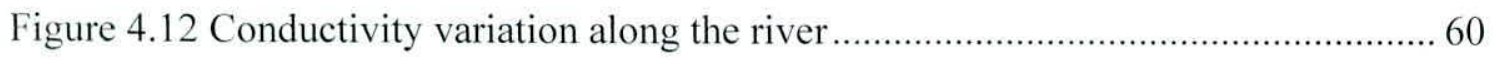

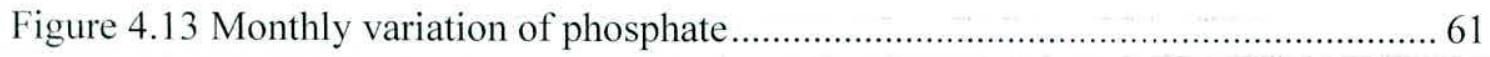

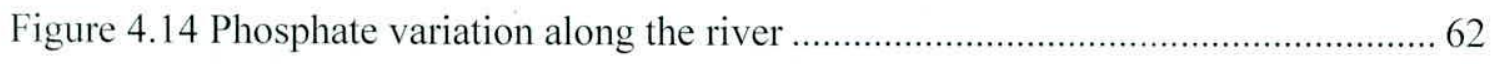

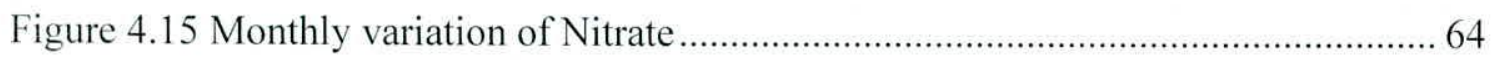

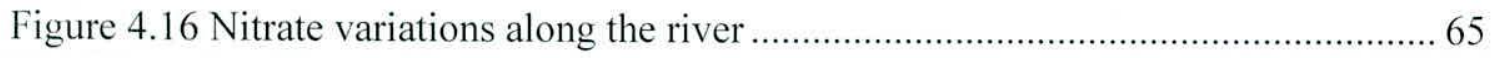

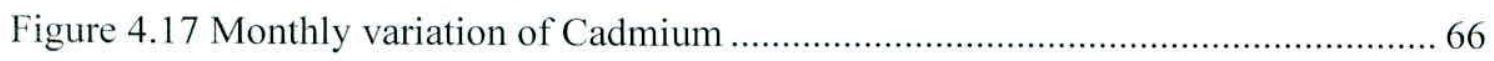

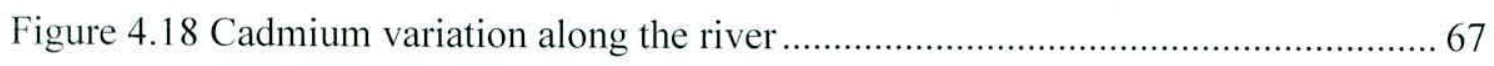

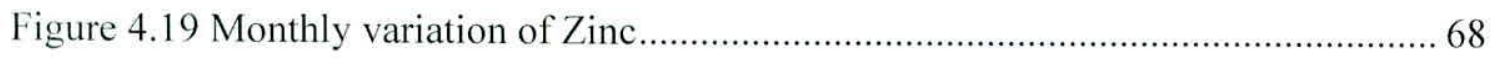

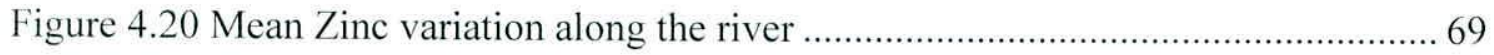

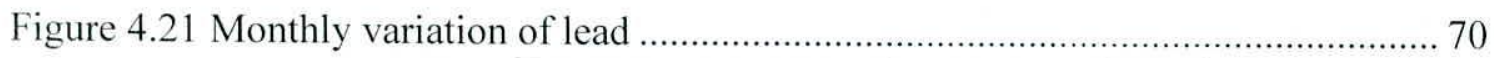

Figure 4.22 Lead variation along the river................................................................. 71

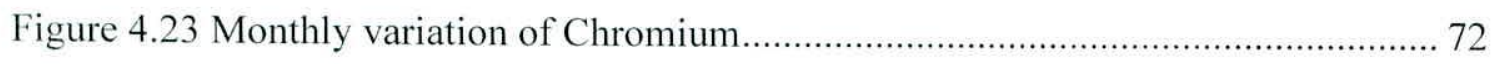

Figure 4.24 Chromium variation along the river ............................................................. 72

Figure 4.25 Monthly variation of Total coliform ............................................................... 73

Figure 4.26 Total Coliform variation along the river................................................... 74

Figure 4.27 Monthly variation of Faecal Coliform ........................................................... 75

Figure 4.28 Mean Faecal Coliform variation along the river............................................ 76

Figure 4.29 Water Quality Index during dry and rainy periods ...................................... 79 


\section{LIST OF ABRREVATIONS AND ACRONYMS}

$\begin{array}{ll}\text { AER } & \text { Agro Ecological Region } \\ \text { BOD } & \text { Biochemical Oxygen Demand } \\ \text { CCME } & \text { Canadian Council of the Ministers of Environment } \\ \text { CEA } & \text { Central Environmental Authority } \\ \text { COD } & \text { Chemical Oxygen Demand } \\ \text { DO } & \text { Dissolved Oxygen } \\ \text { DS } & \text { Divisional Secretariat } \\ \text { EC } & \text { Electrical Conductivity } \\ \text { IP } & \text { Industrial Park } \\ \text { MCM } & \text { Million Cubic Meters } \\ \text { MPN } & \text { Most Probable Number } \\ \text { NWS\&DB } & \text { National Water Supply and Drainage Board } \\ \text { NTU } & \text { Nephelometric Turbidity Unit } \\ \text { WHO } & \text { World Health Organization } \\ \text { WL } & \text { Wet country Low } \\ \text { WQI } & \text { Water Quality Index }\end{array}$




\section{ACKNOWLEDGEMENT}

I wish to express my deepest gratitude to my supervisors, Prof .Nilanthi Bandara, Professor, Department of Forestry and Environmental Science and Dr. C. D. Jayaweera Senior Lecturer, Department of Chemistry University of Sri Jayewardenepura for the invaluable advice and encouragement given to me throughout this research project.

I am indebted to my external supervisor Mr. W.S.C.A Fonseka, Former Chief Chemist of the National Water supply and Drainage Board for guidance and support extended to me during chemical analysis.

I extend my sincere gratitude to Prof. B.M.P.Sinhakumara, chair of the Department, Prof. Hiran Amarasekera, former Head Department of Forestry and Environmental Science, University of Sri Jayewardenepura Prof. Hemanthi Ranasinghe, Dr. Prasanthi Gunawardena and Dr. Upul Subasinghe, for all the assistance given to me during this research.

I express my sincere appreciation to Mr. P. Dias \& Mr. D. C' Wickramaarachchi, Senior Lecturers, Department of Statistics and Computer Scicnci, University of Sri Jayewardenepura for providing me guidance in statistical anlysis of the results.

I also indebted to Mr.Sumitha Sumanaweera, Assistant General Manager, Research and Development Unit, National Water supply and Drainage Board for all the facilities given to me during the research. Thanks also due to Mr. S. Karannagoda Regional Chemist Gampaha, National Water Supply and Drainage Board for guidance given to me during chemical analysis. Thanks are also due to Mr. I. Chandralal, Senior Technician, Regional Laboratory, National Water Supply and Drainage Board, Negambo

I also must thank Mr.I.D. Wijesinghe, Senior Technician, Department of Forestry and Environmental Science, University of Sri Jayewardenepura, for the cooperation given tome during the period of chemical analysis of the research and all the non academic staff for their help during the research.

I am obliged to all persons who gave their fullest support in completing this research, whom I have not mentioned individually 
It is with great honour and gratitude that I pen these last few words for my beloved parents who have put their untiring effort to bring me to this position, which I am today.

Last but not least I must record my deepest and warm thanks to my husband and my sister for the support and the encouragement given to me throughout the research work and preparation . of this dissertation. 


\title{
Investigation of Pollution Extent of Attanagalu Oya: Causes and Effects \\ C.D.K Pathirana
}

\begin{abstract}
Attanagalu Oya; one of the rivers in Sri Lanka is very much used for extraction of drinking water. The longest length of the river course is about $76 \mathrm{~km}$. It llows through two important districts of Sri Lanka serving water for urban population of around $31000 \mathrm{~m}^{3} /$ day. Several small to medium urban centres are located on the main stem of the river and on tributaries. Hence, the river receives much organic waste from the upstream. Industrial discharges and harmful anthropogenic activities are common in the final stretch of the river. This study intends to investigate the water quality variation in Attanagalu Oya along the main stream.
\end{abstract}

Sampling was conducted during a period of two years so as to include the main seasons of the year. Water samples were collected from ten selected sampling locations along the main river including sampling points near the origin of the river, near the river outfall and closest possible locations near the NWS\&DB intakes from the main river. Samples were collected once a month and tested for physical, chemical and biological parameters. Turbidity, COD, BOD, faecal coliform, total coliform and Nitrate levels were examined in each sampling location. Results were used to find out the quality of water by comparing with the standards levels given by the Central Environmental Authority, Sri Lanka. Water Quality Index at each sampling location during both seasons was calculated using CCME water quality index 1.0 tool.

According to the study, Turbidity, BOD, COD, Total coliform and faccal coliform in some downstream sampling locations were higher than the Sri Lankan standards specified for drinking water. Furthermore BOD, COD, nitrate levels and heavy metal concentrations of downstream is very much higher than upstream. However heavy metals of raw water were below the standards. There is a significant difference between the values obtained during the dry and rainy season of the year for COD, BOD, Turbidity faecal coliform and total coliform. According to the calculations, WQI at the beginning of the river is excellent during both dry and rainy seasons. However the WQI gradually declined towards the latter parts of the river. 
The study shows that the river is polluted, the effects being significant in the urban areas, specially the final half of the river. An integrated control of water, land use and waste disposal is necessary in order to prevent the escalation of effects

Among the NWSDB intakes higher attention should be given to the Kotugoda intake. This is the largest intake of the river which currently exceeds the standards for drinking water with conventional treatment. Situation may rapidly change due to industrial discharges of upstream.

Key words: Water quality, Attanagalu Oya, Industrial discharges, Anthropogenic activities, Organic waste 


\section{CHAPTER ONE}

\section{INTRODUCTION}

\subsection{Attanagalu Oya Basin}

\subsubsection{Extent of the basin}

Attanagalu Oya basin is located between Kelaniya and Maha oya river basins and has a catchment area of $736 \mathrm{~km}^{2}$. The Attanagalu Oya rises in low hills situated at the eastern boundary of the basin and flows from east to west up to Kotugoda where it turns towards the North and gradually flows toward the South till it reaches the Seeduwa bridge, across the Colombo-Negambo road. From the bridge, it again flows westwards of the Negambo lagoon. The Longest length of the river course is about $76 \mathrm{~km}$. At its lower reaches, it joins with Uruwela oya and from this point, the river is named as "Dandugam Oya". Above Kotugoda, a man-made canal called Jaela, directly drains a part of the catchment flow. Hence, the runoff from the Attanagalu Oya basin is shared between Jaela and Dandugam Oya.

\subsubsection{Water Resource Data}

\section{A. Rainfall}

A daily rainfall (non recording) gauging network with about 17 stations including the stations in the boundary and just outside the basin is maintained by the Department of Meteorology. There is one recording rainforest station (at Karasnagala) maintained by the Department of Irrigation.

The mean monthly rainfall of the basin was calculated using the station's daily rainfall (Figure 1.1). It is seen that the lowest rainfall months are January and February while the highest rainfall months are May and October (Department of Metrology, 2012). 


\section{Monthly Rainfall (mm) \\ Attanagalu Oya Basin}

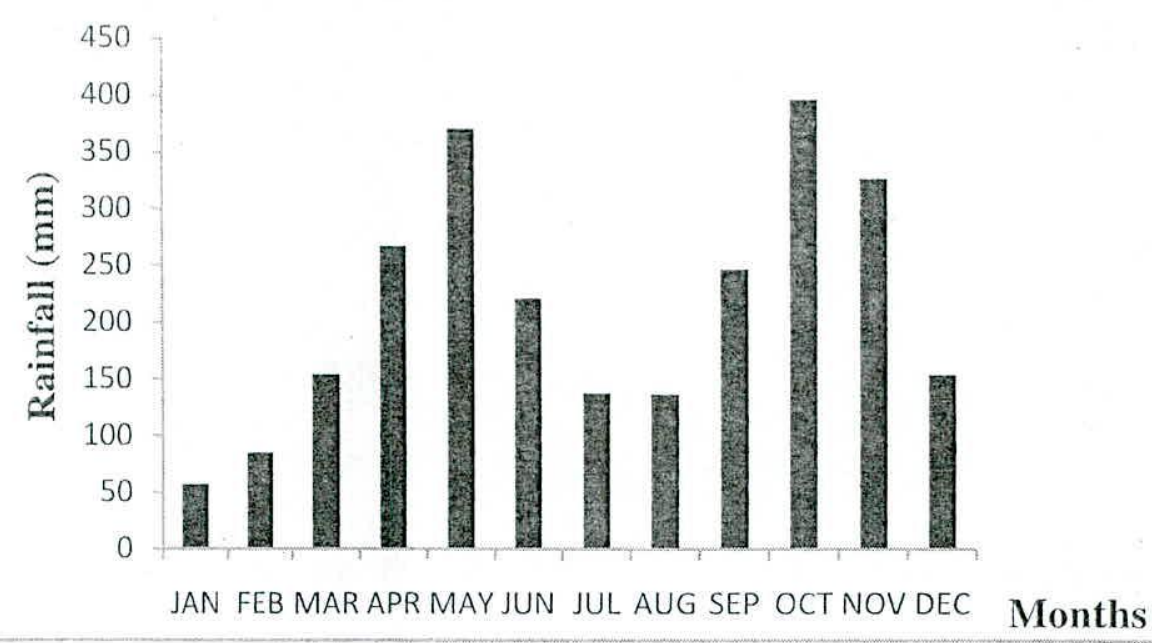

Figure 1.1 Average rainfall fluctuation of the basin

(Source: Metrology Department 2001-2011)

\section{B. Groundwater}

The inland sand aquifers which supply both domestic and industrial water are not stressed at present and thesand aquifer has potential for further extraction. Sand aquifers bordering the Negambo lagoon and Muthurajawela cannot be stressed due to salinity intrusion. The marsh sectors of these areas yield poor quality ground water (NWS\&DB, 2005).

Unconfined aquifers of the basin include alluvial, colluvial and residual lateride aquifers. Of these, the alluvial aquifers and specially the coastal sands provide significant quantities of groundwater (NWS\&DB, 2005).

In the coastal plain, the coastal sand belt forms excellent aquifers in addition to river alluvial. Such sand beds are mainly observed in areas of Ja-Ela Ekala, Katunayaka and Kimbulapitiya. These dune sand deposits are porous and permeable to sustain productive groundwater. River alluvium is thick in the coastal terrain where areas bordering the river have coarse to fine sand profiles offering good groundwater storage. The productivity of alluvium can be expressed as specific capacity of alluvium and it 
ranges from $664 \mathrm{~m}^{2} /$ day to $295 \mathrm{~m}^{2} /$ day from west to east of the basin (NWS\&DB, 2005).

In the areas bordering the Negambo lagoon and to south of the lagoon (Muthurajawela swamp) a thick bed of peat and peaty organic clays exists down to depths up to $7 \mathrm{~m}$ in thickness. The large proportions of water in these aquifers are not portable (NWS\&DB, 2007).

\subsection{Raw Water Utility of Attanagalu Oya}

Water is manly used for drinking, irrigation and industrial purposes. Considering the total demand and the supply, the estimated average value of the resource is 847 million $\mathrm{m}^{3}$. Present use of resource is 71 million $\mathrm{m}^{3}$ which is expected to rise up to 145 million $\mathrm{m}^{3}$ in year 2025 (NWS\&DB, 2005). This will be a $6 \%$ increment from the current demand. So there is a potential to reduce the water flow to the downstream of the river.

\subsubsection{Drinking}

The most important use of the water in the Attanagalu Oya is for the supply of drinking water. At present there are seven water supply schemes in the basin serving an urban population of around $31000 \mathrm{~m}^{3} /$ day (NWS\&DB, 2005). Of the intakes three are located along the main river and others are scattered along the tributaries.

Through these intakes Attanagalu Oya serves a population of about 63300 (NWS\&DB, 2005). It is estimated that $83 \%$ of the urban population of the basin has access to pipe borne water. Other $17 \%$ depend on ground water. However, only $7.7 \%$ rural population in the basin has access to the pipe borne water while the remaining $92 \%$ of the rural population depend on their traditional supplies (NWS\&DB, 2005). Apart from this the people in the vicinity use the water for domestic purposes.

In addition to these piped water supply schemes, there are many independent users having their own source of supply such as shallow dug wells for small domestic supplies, deep tube wells for industrial consumers and small number of informal surface water abstractions and catch pits. 